\title{
Unified in response to rising powers? China, Russia and EU-US relations
}

\author{
Marianne Riddervold and Guri Rosén
}

\begin{abstract}
How do the EU and the US respond to rising powers making territorial claims? Are they unified in their approaches, and if not, where do their policies diverge? Transatlantic unity or dissent in response to main geopolitical issues has implications for our understanding of transatlantic security relations and for the future of global power-relations more broadly. We explore EUUS posi- tions and responses to Chinese advances in the South China Sea and Russia's actions in the Ukraine. Two hypotheses guide our analysis: First, that they cooperate to balance against these powers, hence strengthening transatlantic relations. Secondly, that the EU is developing policies independently of the US, thus weakening EU-US relations. Our findings suggest that despite a general coherence of American and European stance in both cases, the level of coordination varies. Instead, we find signs of weakening EU-US security relations as the EU develops a more autonomous policy vis-à-vis the US.
\end{abstract}

Keywords

Transatlantic relations; security policy; emerging powers; European Union

\section{Introduction}

Most observers agree that the international security order is changing from unipolarity under US hegemony to what is referred to as a multipolar, bipolar, polar or apolar system (Brooks and Wohlforth 2016). Underlying this argument is not so much that the United States (US) is becoming weaker or losing its military might, but rather that other countries are becoming richer and more powerful. It is the rise of emerging powers - Brazil, China, India, Russia (the socalled BRICs countries) - that is redefining the international global order by altering the power relations amongst states. In this article we aim to contribute to a better understanding of if and how these global power shifts influence EU-US relations by studying how the European Union (EU) and the US have responded to Russia and China's territorial claims in Ukraine and the South China Sea. Are these developments weakening EU-US relations, or have they instead triggered stronger cooperation between the EU and the US? This has not been explored systematically in the existing literature. EU-US unity or dissent in response to rising powers has deep implications not only for our understanding of transatlantic security relations but also for our understanding of future global power-relations more broadly. After all, making 
territorial claims - whether in other states or in international waters - is the most fundamental way a state can seek to increase its external influence.

From a neo-realist perspective, one might expect the rise of emerging powers to lead to a strengthening of relations between the EU and the US. Since the Second World War, the US and (Western) Europe have been linked together through a variety of different institutions, not least in the realm of security. In the face of rising powers, one would expect that the existing hegemon (the US) would work together with its junior partner (the EU) to counter-balance the powers of rising states and maintain its global and regional power positions (Waltz 2000). Assuming an anarchical world order where stability is maintained by a balance of power amongst a few states or by a strong global hegemon, leading neo-realists have indeed predicted such developments since the end of the Cold war (Waltz 2000).

On the other hand, Russia and China's behavior may potentially also pose a challenge to EUUS unity and hence weaken their relationship. Strategically, the US and the EU seem to have increasingly different priorities. The US has traditionally controlled the South China Sea through its military power and its alliances with states in the region (Posen 2003). China's claim to gain territorial control of most of the South China Sea threatens this position and the US' traditional allies in the region (Mearsheimer and Walt 2016). While for the EU, Russia's invasion of Crimea and efforts to control East Ukraine exposes the stability and security of the EU's nearest neighbors and even some of the member states. Beyond these strategic considerations, a dominant strand in the literature on the EU's foreign policy depicts the Union as an increasingly confident and internationally autonomous international actor (Jørgensen et al. 2015). A corollary is that the EU is not only taking on a bigger international role but also that it increasingly leads a different type of foreign policy than the US, with reference to for example the EU-US divisions over Iraq (Anderson et al 2008; M.E. Smith 2015, M.E Smith 2018 and Smith 2018 this volume). From such a perspective, one might hence expect the EU to choose a different route than the US: Rather than cooperating with the US in line with US preferences, the EU may be developing an autonomous and different policy to that of the US, hence weakening EU-US relations.

To tease out if and how EU-US relations are affected by Russia and China's territorial claims, the article proceeds as follows. We first draw on existing literature and the Special Issue introduction to set out the two hypotheses of EU-US relations opposite China and Russia in 
more detail. The subsequent analysis is structured accordingly, case by case. The conclusion sums up the findings and discusses their implications.

\section{Analytical Framework and hypotheses}

\subsection{The neo-realist balancing hypothesis: Strengthened EU-US relations}

The first hypothesis builds on a neo-realist perspective and suggests that EU-US relations have strengthened in response to territorial claims, as the EU joins forces with the US as a junior partner to counter-balance the powers of these rising states (Waltz 1979, 2002). With its focus on power politics, security, sovereignty, territorial conflicts and war, realist perspectives are often used to describe and explain structural power shifts and relations, as new powers rise and old ones respond. A key proposition derived from neo-realist theory 'is that the balancing of power by some states against others recurs' continuously, at the regional or the global level (Waltz 2000, 27). The international system's core feature is that it is anarchical, composed of strategically rational states whose behavior is driven mainly by the aim of securing their territorial integrity and the security of their populations (Mearsheimer 2014, Posen 2003, Waltz 2000).

The rise of China, Russia and the other BRIC countries has thus led to a revival of realist perspectives in the study of international relations, including in EU foreign and security policy studies (Flockhart 2016, Mearsheimer and Walt 2016.) As argued by Stephen Walt: 'When the Cold War ended, there was a brief period where a few politicians and a few scholars naively believed power politics was over (...) but instead we have seen power politics come back with a vengeance. The conflict in Ukraine is one obvious example, and so is China's growing assertiveness'. ${ }^{1}$ A neo-realist hypothesis suggesting that EU-US relations will strengthen as part of a bigger geo-political balancing game would also be in line with the argument that the EU and the US share an interest in cooperation to protect 'US leadership against rising powers' (Youngs 2010, 32). Although realists do not expect states to give up their sovereignty to common institutions, they might come together in security alliances to be collectively stronger in the face of other powers, which is how both NATO and EU foreign and security cooperation is explained from a neo-realist perspective (Hyde-Price 2006).

\footnotetext{
${ }^{1} \mathrm{https} / / \mathrm{www} . \mathrm{munplanet.com/articles/international-relations/on-international-relations-theory-and-practice-a-}$ special-interview-with-professor-stephen-walt.
} 
If the strengthening/balancing-hypothesis is substantiated, one would expect the EU to cooperate closely with the US opposite China and Russia to make them give up territorial claims in areas of strategic interest to the EU and the US. This means first; that the EU and US will be united in their positions and policies towards Russia and China. One would hence expect to find references on both sides to the strategic importance of establishing a strong Western force to balance against China and Russia. US and EU policies would be be coordinated and consistent and the EU would follow the US' lead as a junior partner. One would also expect EU and the US to cooperate and to deliberately 'develop complementary strategies and a division of labour in their dealings' with Russia and China (Tunsjø 2015, 151). This division of labor could be functional and linked to means, with the US projecting its military power and the EU drawing more on its traditional soft power economic tools in their policies towards Russia and China (Hyde-Price 2006). There could however also be a geographic element to this division of labour, with the EU focusing mainly on its near abroad and hence the Ukraine crisis, and the US being more engaged in the South China Sea (Tunsjø 2015).

\subsection{The autonomy hypothesis: Weakening EU-US relations}

It might however also be that EU-US relations have weakened in light of rising powers making territorial claims, if the EU instead of allying with the US develops its own policies, independently of and in contrast to those of the US. Since the 1990s, a growing literature has argued that the EU has become a strong foreign policy actor in its own right (Jørgensen et al. 2015). The EU has for example developed a wide range of foreign policy tools, including military capabilities and the EU increasingly speaks with one voice at the international arena. With the EU's new Global Strategy and in the face of recent crises, the EU has moreover expressed ambitions of further developing an autonomous foreign and defence policy (see Howorth 2018 and and M.E. Smith 2018 this volume). It may hence be that rather than allying with the US as part of a global and regional geopolitical balancing game, the EU seeks to develop a policy that is independent of the US opposite China and Russia.

The extent of the EU's autonomy has been central to the debate about its "actorness" on the international stage (e.g. Bretherton and Vogler 2006). On the one hand, autonomy refers to the independence of the EU apparatus from the member states (cf. Jupille and Caparoso 1998). On the other hand, autonomy means the extent to which the EU develops and leads a policy independent of other international actors. Along these lines, Biscop (2013) has suggested that the American pivot to Asia "forces strategic autonomy upon Europeans". An autonomy hypothesis would also be in line with studies suggesting that the EU is a different type of foreign 
policy actor than the US and that this serves to weaken EU-US relations evident for example in EU-US divisions over Iraq (M.E. Smith 2015) or the International Criminal Court (Deitelhoff 2009).

If this weakening/autonomy hypothesis is substantiated, one would expect first, that the EU expresses an ambition of developing an autonomous EU policy towards China and Russia. Although the EU and the US might fulfil separate roles, one would expect this difference to reflect the EU's own ambitions of conducting an autonomous policy. Second, this ambition must be followed up in the EU's actual policies, also in cases where EU policies are in conflict with US' policies or preferences. Indeed, the strongest evidence of a weakening-hypothesis would be that the EU explicitly acts in opposition to the US' wishes in concrete cases. A third indicator of an autonomous policy is that the member states chose cooperation within the EU's Common Foreign and Security Policy (CFSP), and reduce their attention to NATO.

\section{Analysis}

To study EU-US relations in the context of emerging powers' territorial claims, we explore their positions and policies vis-à-vis China and Russia in response to their advances in the South China Sea and in Ukraine. The main data sources include official EU and US documents as well as 14 interviews across EU institutions and member states, as well as in NATO. To further triangulate our data, we have compared our findings to existing research and observers' reports.

\subsection{EU-US and Russia: The Ukraine Crisis}

First we look at the Ukraine case. Has this served to strengthen or weaken EU-US relations? After several years of negotiations, President Yanukovich took EU-leaders by surprise when he announced that tUkraine would suspend the preparations for an Association Agreement with the EU, favouring instead closer ties with Russia. ${ }^{2}$ Protesting crowds gathered in Kiev's Independence square, often also called the Euromaidan. Yanukovich fled and shortly after, in early March 2014, Russia annexed the Crimean peninsula, and in the subsequent months seized control over territories in Eastern Ukraine. Responding to the events, the EU devised a threestep approach, where it first broke off diplomatic relations, secondly, introduced individual sanctions such as travel bans and asset freezes. Finally, shortly after the downing of the Malaysian airplane MH 17 in July 2014, the EU announced its first wave of economic sanctions targeting entire sectors. These encompass restrictions on Russian financial institutions, an

\footnotetext{
${ }^{2}$ Euractiv 21/11/2013.
} 
embargo on arms trade, export ban on dual goods, and a curtailment of Russian access to sensitive technologies, particularly in the field of the oil sector. ${ }^{3}$ At the time of writing, the sanctions are still in force.

On the one hand, there was clearly a lot of coordination efforts between the EU and the US in response to Russian aggression in Ukraine. When announcing the first round of American sanctions in the beginning of March, 2014, President Obama stated: 'We took these steps in close coordination with our European allies' (White House 2014). This was echoed by the EUPresident, van Rompuy, who underlined that the EU and the US 'have a strong and coordinated position' on Ukraine. ${ }^{4} \mathrm{G} 7$ became a key forum for the development of a common policy vis-àvis Ukraine and Russia. ${ }^{5}$ These initial talks were instrumental in settling 'what was possible and not possible' (interview, 12/01/2016\#1). The size of the conflict demanded coordination. When developing a sanctions regime, greater coalitions are needed to avoid escape routes (ibid.).

On the other hand, although they cooperated on sanctions, there is little evidence to suggest that there was a coordinated balancing act under US lead vis-à-vis Russia over Ukraine. One could argue that to the US, Russia represents a regional power, and hence does not have to be balanced. According to Böller and Werle $(2016,326)$, the US does not perceive of Russia as a security threat. Russia is mentioned in the American security strategy, but only as a challenge in the context of international terrorism (ibid.). By contrast, the EU's Global Strategy (2016) states: 'Russia's violation of international law and the destabilisation of Ukraine, on top of protracted conflicts in the wider Black Sea region, have challenged the European security order at its core'. When the Ukraine crisis erupted, however, the EU's member states had diverging positions on to what extent the crises represented a security threat - depending on geography and historical ties (Sjursen and Rosén 2017, 26). Countries such as Poland and the Baltic states were explicit about the security implications of Russian advances in the Ukraine, but members in the south of Central Europe hesitated in taking a firm stand towards Russian aggression (Forbrig 2015). Polish Foreign Minister, Radoslaw Sikorski, complained that the EU's reaction was slow compared to the US, which quickly affirmed its determination to guarantee the security of the Eastern and Central European countries, for example through the deployment of training troops and US airborne companies to Estonia, Latvia, Lithuania and Poland. ${ }^{6}$ Thus, the US

\footnotetext{
${ }^{3}$ European Council, 29/03/14.

${ }^{4} \mathrm{http}$ ///edition.cnn.com/2014/03/26/politics/ukraine-crisis/index.html

${ }^{5}$ Russia was expelled from G8 after its annexation of Crimea.

${ }^{6} \mathrm{http}$ //www.spiegel.de/international/europe/polish-foreign-minister-discusses-weak-eu-position-in-ukrainecrisis-a-957812.html.
} 
demonstrated a willingness to counterbalance Russia in Eastern Europe - on behalf of its NATO-allies - while the EU was more hesitant. What is more and contrary to a coordinated balancing hypothesis, scholars have argued that the EU did not even understand how its rapprochement with the Ukraine would upset the Russian government (e.g. Auer 2015, MacFarlane and Menon 2014). Gehring et al. (2017) have claimed that the EU acted as a great power in the security crisis over Ukraine, albeit inadvertently. Their argument is that the EU 'unintentionally challenges major security interests of other great powers' through its 'communitarized external action based on low-politics strategies' (ibid, 728). Thus, one could argue that the EU did not understand, or at least did not take into consideration a type of "balancing game" when devising and conducting its policies in its Eastern neighborhood.

Still, throughout the crisis there is evidence of a division of labor developing between the US and the EU, particularly as regards the diverging roles played by the EU on the one hand, and by NATO - led by the US - on the other. The American support to the Eastern Europeans does not indicate a division of labor in geographical terms, where Europe takes care of its own neighborhood, leaving the US to balance against China (cf. Tunsjø 2015). In functional terms however, NATO deals with 'tasks mainly in the higher intensity field of peace enforcement and peacekeeping', whilst over time the EU has emerged as an actor geared towards conflict prevention in situations where intensity is lower and where it can draw on a combination of military and civilian instruments (Schleich 2014: 188). Being the world's only hegemon, and Europe's long-term guarantor for security, some studies have indeed emphasized how the EU's response to Russia's aggression has been dovetailing the US (e.g. Haukkala 2015). In February 2014, a leaked conversation between Victoria Nuland from the US State Department and the US Ambassador to the Ukraine was reported to have expressed her impatience with the EU in not-so-diplomatic terms. Nuland's frustration signals that the EU was not acting according to the State Department wishes, but it also demonstrates the differences between the reactions of the EU and the US. At the outset, the US did try to push EU member states to increase pressure on Russia (interviews 18/11/2015, 12/01/2016\#2). Still, there are not many signs that the US attempts to pressure the EU to act was what determined the course of action, which suggests that the EU was not a junior partner to the American endeavor.

All interviewees were adamant that the EU was seen as the appropriate actor to be the forerunner in this particular conflict. The EU had been investing a great deal of resources and prestige in extending an Association Agreement to Ukraine, and for EU to be involved was a 'natural response' (interview, 18/11/2015). Pursuing the NATO-line would have entailed an 
escalation of the conflict, so 'it was deemed appropriate to go through the EU - not to trigger a stronger response from Russia' (interview, 12/01/2016\#2). It was also the EU that took the lead in the diplomatic efforts vis-à-vis Russia through the Normandie-format, comprising France, Germany, Russia and Ukraine, resulting in the Minsk II-agreement of February 2015. This was a distribution of roles preferred on both sides of the Atlantic. Once the EU had adopted its sanctions regime had been established, the US took a step back (interview, 12/01/2016). The Americans preferred to "outsource" the mediation efforts to the EU (Larson 2018). There was mutual understanding that the Russians would never negotiate with the Americans (interview, 12/01/2016\#1).

At the same time, the US was quick to reassure the security concerns of the Baltics and Poland. The initial decision to deploy troops and fighter jets was reached through bilateral deals, but the US was also instrumental in coordinating the NATO-response (interview, 12/01/2016\#1). The question is whether and to what extent this division of labor testifies to a strengthening of the relationship between the EU and the US. For that to be the case, this would have to be a policy devised in EU-US tandem. Beyond sanctions, that the US took charge of the 'hard security aspects' was described by one interviewee as an 'unofficial division of labour' $(12 / 01 / 2016 \# 1)$. The coordination of the work in NATO and the EU also seems to have been looser and less concrete - in line with the existing literature on NATO/EU-relations (e.g. Duke and Gebhard 2017). This means that the US will coordinate within NATO with EU-member states that are also NATO-members, but not primarily with the EU as such. Thus, although the respective roles of the US through NATO and the EU follows the expected division between hard and soft security, there is little to suggest that the division of labor was coordinated - apart from the sanctions regime. Furthermore, there are few signs of the EU being a junior partner to the US in developing its own policies to adjust to the American strategy.

By contrast, EU governments stressed that Europe's relations with Russia were of a different nature than those of US-Russia relations. In the words of one interviewee, issuing sanctions is easier for the US because its economy is less intertwined with Russia, because it does not need to reach agreement among 28 member states, but also because its fundamental attitude towards Russia is different from the EU's (interview, 16/12/2015). In a similar vein, Sweden's Prime Minister, Fredrik Reinfeldt underlined that Europe's integration with Russia is enormous, financially, economically and in terms of energy: 'We need to remember that when the US is talking about economic sanctions against Russia, they do not have the same relationship with 
Russia that many of the European states have'. ${ }^{7}$ Thus, Haine $(2015,1007)$ has argued that the Ukrainian crisis represents "a point at which Europeans finally understood that a European solution needed to be found to what is essentially a European problem". This raises the question whether the Ukraine-crisis led to a weakening of the EU-US relationship where the EU displays an ambition to conduct an autonomous policy towards Russia?

The EU and the US have made an effort to appear united on the crisis in Ukraine. In the words of President Barack Obama in March, 2014: 'If anyone in the Russian leadership thought the world wouldn't care about their actions in Ukraine or that they could drive a wedge between the European Union and the United States, they clearly miscalculated'. ${ }^{8}$ Furthermore, he underlined that the EU and the US reacted not 'because we're trying to keep Russia down, but because the principles that have meant so much to Europe and the world must be upheld.' Recent studies have argued that a main impetus to act, both on part of the EU and the US was Russia's breach of international law and the need to protect national sovereignty and territorial integrity (e.g. Sjursen and Rosén 2017, Böller and Werle 2016).

Nevertheless, this general concord on the justifications for a common response masks some significant differences. First, while the immediate trigger of the crisis was the rapprochement between the EU and Ukraine, the prospects of a Ukrainian NATO-membership is another factors held to have ignited Russia's geopolitical and strategic assessments. As argued by Howorth $(2017,125-126)$, NATO signaled the prospect of a possible membership for Georgia and Ukraine, despite Germany and France having blocked such a move. While this reflects the US-position on NATO-expansion: 'there can be little doubt that Washington's policy towards Central and Eastern Europe has not made life easier for the European Union in its own dealings with its Eastern neighbours'. This serves to illustrate how the EU and the US have fundamentally different perspectives on their relationship with Russia. Before the Ukraine crisis, 'there was next to no EU-US dimension to their relations with Russia to speak of' (Young and Birchfeld 2017, 28).

There are of course also diverging interests opposite Russia within the Union itself. The EU's policy vis-à-vis Russia has been described as a balancing act between different member state interests (Casier 2016). But the important point in this context is how the crisis was conceived of as a European crisis (see Sjursen and Rosén 2017): 'This was a democracy issue and the EU

\footnotetext{
${ }^{7}$ Sweden, Riksdagen, 2014.

${ }^{8} \mathrm{https}$ ://www.politico.com/story/2014/03/barack-obama-russia-crimea-105043.
} 
was much further involved. So it was EU's obligation to do something' (interview, $12 / 01 / 2016 \# 1)$. At the same time, there was a need to proceed cautiously since to the EU, Ukraine-policy is de facto Russia-policy (interview, 16/12/2015). Countering critics of the difference between the US and EU's approaches, the German Foreign Minister, Steinmeier, held out that the EU-sanctions were designed to 'keep the door open for political solutions'. He also defended the EU's position from those who said that the response was too soft, and that the EU should show more strength and force in its foreign policy: 'One could say that. Except that you have to be very clear about what the alternative is. And what exactly would it be, beyond diplomatic pressure? Anyone who really wants to show this alleged strength must be prepared to do something which I am not prepared to do, namely to countenance the idea of using force in such a situation'. ${ }^{10}$ These statements are emblematic of the core difference between the EU and the US - the stakes were higher for the Europeans, both in economic and security terms. Thus, it was important for the EU to determine its own policies in the Ukraine crisis.

Secondly, there was a strong wish in the EU to stand united in the face of the Ukraine-crisis. This was apparent even before debates had begun about what policies the EU should choose: "What was striking during all our debates that we had, and at whatever level we had them (...) was that there was a sense of a clear need for unity, and that was always overcoming everything else. (...). This was quite interesting and something that I have never found perhaps to the same level on other issues." (Pierre Vimont, United Kingdom, House of Lords 2014, 345). This observation is confirmed through the interviews: 'No one wanted to break that stance against Russia' (interview, 12/01/2016\#2). Moreover, it is described as a significant change compared to the conflict in Georgia in 2008: 'We never discussed whether the EU should or should not do something. Everyone agreed that we should do something - the question was how much and how far' (interview, 12/01/2016\#1). This gives an indication of the level of ambition on the part of the EU to lead and preserve European autonomy. According to German Foreign Minister Steinmeier, 'Europe must stand as one and issue a common reply. Russia knows that, if splits were to arise within Europe on such a key issue, this would put an end to Europe's common foreign policy before it ever began'. ${ }^{11}$

\footnotetext{
${ }^{9}$ German Ministry of Foreign Affairs, 19/03/14.

${ }^{10}$ Bundestag, 07/05/14.

${ }^{11}$ German Ministry of Foreign Affairs, 2014.
} 
Not only was the EU preferred to act in order not to escalate the conflict with Russia, but interviewees also held that 'EU was best equipped to deal with this situation. The tools that the EU possesses are the right ones' (interview, 12/01/2016\#1, \#2, \#3). Some interviewees even questioned the US' actual support with Ukraine: "The US is not helping out that much, they don't pay for the sanctions. We do" (interview 24/10-2017). Thus, the Ukraine conclict was clearly perceived as a crisis where the EU could and should take the lead, as a coherent autonomous actor.

\subsection{EU-US and China: The South China Sea Conflict}

What then about EU-US relations vis-à-vis China? The South China Sea has been the subject of territorial disputes for centuries, but due not least to China's aggressive and increasingly militarized behaviour, tensions have increased in recent years (Yuan 2012). A particularly difficult area is the Paracel and Spratly Island chains, which China claims to control for historical reasons, in conflict with US allies in the region. Challenging this claim, in 2013 the Philippines took China to an arbitration tribunal under the auspices of the UN Convention on the Law of the Sea (UNCLOS). Although the tribunal backed the Philippines' case, China has boycotted the ruling and says it will not be bound by it. ${ }^{12}$

At the outset, the balancing hypothesis seems particularly relevant for understanding EU-US relations in the South China Sea case. After all, this is an area far away from the EU's neighborhood, making it particularly likely that the EU - if it at all has a common policy supports its traditional ally, the US, by drawing on its soft power tools. From an American perspective, China is a bigger threat to its global hegemony than Russia. 'Command of the global commons' (Posen 2003) is key to the US' global power and it is 'an essential ingredient of achieving great-power status in the future' (Yuan 2012: 11). When announcing the US' pivot to Asia in 2011, Hillary Clinton, referred to the Asia-Pacific as 'the key driver of global politics' arguing that 'U.S. commitment there is essential (...) for continued American leadership' ${ }^{13}$ Although the US also applies diplomatic means, it has moreover made it clear that it "will maintain the necessary military presence and capabilities to protect U.S. interests and those of allies and partners (...) deter conflict and coercion and respond decisively when needed', in line with a neo-realist perspective. ${ }^{14}$ So, is the EU part of this balancing game, joining the US as a

\footnotetext{
${ }^{12}$ Why is the South China Sea contentious? BBC News 12/7-2016, http://www.bbc.com/news/world-asia-pacific13748349

$\frac{13748349}{13} \mathrm{http} / / /$ foreignpolicy.com/2011/10/11/americas-pacific-century/

${ }^{14} \mathrm{https}$ //www.defense.gov/News/Article/Article/614488/us-outlines-asia-pacific-maritime-security-strategy/
} 
soft junior-partner vis-à-vis China, suggesting a strengthening of EU-US relations in the face of rising powers?

Not very surprisingly, the EU is indeed a soft power in the region, foremost relying on diplomatic and economic tools in its dealings with China. (see Kirchner et al 2016). Officially, both the EU's and the US' approaches to maritime disputes in Asia is that of 'principled neutrality,' (Duchâtel 2016: 53). Put briefly, this implies that they don't have official opinions on what islands belong to whom (Interviews 2017). ${ }^{15}$ Both parties underline the importance of respecting UNCLOS and relevant court rulings. 'China has a very different interpretation of international law - focusing on sovereignty rather than freedom of navigation (Pejsova 2016a: 7). Hence, from a Chinese perspective, the EU is still widely seen as being part of "the West" together with the USA' (Kirchner et al 2016: 4).

In reality, however, EU and the US are less united in their policies than one would expect following a balancing hypothesis. First, we do not find justifications of the EU's China policies referring to the need to work with the US to balance China's power in the region. While the US explicitly uses a balancing language, EU policy documents and interviewees foremost refer to the need to work with both parties and in particular building regional cooperation through the Association of Southeast Asian Nations (ASEAN) (Interviews 2017). Second, EU and US' positions and policies deviate more than one would expect on the basis of their official neutral, UNCLOS focused policies. The US' main concern in the region is not only linked to open trade lines but more importantly to the freedom of navigation for its naval fleet. The ability to deploy forces and freely patrol and navigate the area is crucial to maintain its regional hegemony. Thus, although 'the US says it does not take sides in territorial disputes... (it) has sent military ships and planes near disputed islands, calling them "freedom of navigation" operations to ensure access to key shipping and air routes'. ${ }^{16}$ Without doubt, Chinese territorial control of the South China Sea would make the US' presence impossible.

The EU, on the other hand, is mostly concerned with stability and open trade routes. As argued by Kirchner et al (2016: 4) '(w)hile the US is balancing China in the [South China Sea] on the whole 'EU-China relations - in contrast to U.S.-China relations - are not marked by 'balance of power' considerations'. The following quote from a high-level EU official is telling: 'The

\footnotetext{
${ }^{15} \mathrm{https}$ //www.defense.gov/News/Article/Article/614488/us-outlines-asia-pacific-maritime-security-strategy/

${ }^{16}$ Why is the South China Sea contentious? BBC News 12/7-2016, http://www.bbc.com/news/world-asiapacific-13748349
} 
EU and the US have different perspectives of what freedom of navigation means. For the US it is about maintaining the US hegemony. For the EU it is about free sealines' (Interview, 24/102017). And for this reason, the EU does not come out strongly in support of the US. Instead, 'the EU does not have a strong position on the South China Sea' territorial dispute' (Interview 25/10-2017) and is careful to avoid any comments on sovereignty issues, apart from the standard line that China should clarify its claims and respect international law (Duchâtel 2016).

Third, and contrary to what one would expect if there is a functional division of labour between the EU and the US, there is little coordination between the EU and the US regarding the South China Sea. Undoubtedly, the EU has 'discussions with the US on how the EU can contribute. We talk to them regularly on Asian issues,' including the South China Sea (Interview 27/102017). Similarly, 'the US has realized it needs allies, support in the South China Sea. So it constantly asks for our support. The Americans have always asked us: Do more please, and do more of the things that we want (ibid). However, according to our interviewees, 'the US doesn't want the EU to be an [independent] actor, it wants the EU to follow its lead. But the EU doesn't want to take sides' in the conflict (ibid). Because 'the US doesn't think the EU is strategic enough, it wants us in the economic realm' (ibid). In line with this, the US does not want the EU to be present at high level political meetings where Asia-Pacific security issues are discussed by countries such as China, the US and Russia (Interviews 2017). Actually, according to the interviewees, 'the US is open in saying that Europe can't be trusted on this, based on its dealings with China' (Interview 17/10-2017). Although 'the EU wants to be part of the South Asia security structure, the US doesn't really want that' (Interview 25/10-2017).

In sharp contrast to US policies, at least some in the EU is even less concerned with whether or not China or the US have control over the area: Several of our informants argued that the South China Sea would remain open for commercial transport even if under Chinese territorial control (Interviews 2017). Although this is not the official EU policy, it nonetheless suggests that the EU and the US' positions on the South China Sea deviate more than one might expect in light of the historically strong EU-US relationship, and definitely more than would expect on the basis of a balancing hypothesis. Perhaps the strongest evidence that there is neither a functional nor a regional EU-US division of labour as part of a global balancing game is our interviewees' claim that the US unsuccessfully attempted to link its policies vis-à-vis Russia to the EU's policies vis-à-vis China. According both to high level EU diplomats and to others present at EU-US meetings, the US explicitly asked the EU to come down on the US' side in its conflict with China over the freedom of navigation in the South China sea in return for its support on 
Ukraine. For example, 'at a multilateral event in Japan I remember that the US very straight forward said "we helped you out in Ukraine, now you have to help us out with China and the South China Sea" (Interview 17/10-2017) However, as put by the interviewees, 'just because the US asks doesn't mean we should do it' (Interview 27/10-2017). 'The EU would not compromise its relationship with China for the sake of US hegemony' (Interview 24/10-2017).

Does this then mean that the EU-US relations towards China regarding the South China Sea are weakening as a result of the EU becoming more assertive and more independent, increasingly conducting a policy that is autonomous to US? In line with a weakening hypothesis, the data suggests that the EU indeed has ambitions of becoming a player in the region and that it is acting independently of the US. On the one hand, one should not overestimate the importance of the EU as a security actor in the South China Sea. After all, the EU has limited means, and is not traditionally seen as an important security actor in the region by other states. On the other hand, one should not underestimate the EU's ambitions and policies towards the region and their implications for EU-US relations either. According to observers, 'the EU makes a bigger contribution to security in the South China Sea than most people think' (Interview 25/10-2017). With the Global Strategy, the EU has ambitions of becoming a global actor, including in the South China sea, where 'the EU will contribute to global maritime security, building on its experience in the Indian Ocean and the Mediterranean (Council 2016. Also see Howorth 2018; M.E Smith 2018, Smith 2018 this volume). All the interviewed EU officials moreover underlined that the EU 'has a clear ambition. The EU wants to come in and make a contribution' regarding the South China Sea conflict (Interview 23/10-2017). There is also 'a clear EU strategy and the EU works with a long term perspective on how' to become more involved as a security player in the region (ibid). This policy is different from the US' balancing approach, and is also perceived this way from a Chinese perspective: 'Chinese relations with the EU are not seen in the context of the Great Power rivalry that is often detected in its relations with the United States' (in Kichner et al 2016: 4).

Rather than joining the US as a junior partner, the EU's approach to this part of the global commons is to find ways to institutionally manage this conflict (Interviews 2017. Also see Riddervold, 2018). EU staff also seem to believe that the EU can and should play a bigger role in the region, arguing for example that 'it is possible for the EU to be bigger... I am impressed by the EU approach here, the intelligence in this' (Interview 23/10-2017). As suggested elsewhere in this Special Issue (see M.E. Smith 2018, this volume), this might in itself prove to be a factor that strengthens the EU's engagement and independence of the US vis a vis China. 
Some of the interviewees also revealed that there have been internal discussions on whether the EU should deploy a naval crisis-managament mission in the area (Interviews 2017). The fact that the French frigate, Jeanne D'Arc, in 2016 did a freedom of navigation patrol in the South China Sea, with UK helicopters, Dutch personnel and an EU officer on board, further sends a 'certain signal. It shows that we have a position and want to be there' (Interview 27/10-2017). Data also suggest that the EU's approach may serve to weaken EU-US relations: 'Two parallel realities are emerging between the EU and the US. The EU focuses on ASEAN, on a regional cooperation. The US on bilateral relations, on its hard power. The US has a quid pro quo approach' (Interview 23/10-2017). Most importantly - the EU conducts its particular policies in relation to China even in cases where it has explicitly been asked by the US to act differently and despite its possible implications for the EU-US relationship. As argued by Foot (2016), 'the China phenomenon is frequently depicted at official and unofficial levels as having put European-US ties under strain (...). While Europeans have few strategic assets in the AsiaPacific region, the US will expect other forms of support, probably to include economic and diplomatic sanctions. In the absence of that support, the strain in ties is likely to evolve into a deep fracture' (Foot 2016).

One example of such disagreements between the EU and the US is that most EU member states are in the Asian investment bank, despite the fact that the US has urged allies to think twice before joining the China-led bank' ${ }^{17}$, and has condemned 'the constant accommodation of China' by UK, Germany and other European states. ${ }^{18}$ (Twining 2015: 1). Another example directly related to the South China Sea territorial conflict is the EU's response to the UNCLOS arbitrary court ruling in 2016. In this case, the EU came out with a much weaker statement vis a vis China than the US wanted and explicitly asked for (Interviews 2017). Before the ruling on the conflict between the Philippines and China, the EU could claim that it was neutral on the issue. However, with an international court decision clearly in favour of the Philippines, the EU needed to come out with a statement in support of the ruling and hence come down on the 'US side' side. After all, 'if we say we are for a global, rule-based order we have to stay with it' (Interview 24/10-2017). Coming to an EU agreement on a statement in support of the Philippines and hence indirectly the US however proved more difficult than anticipated. As explained by our interviewees (Interviews 2017), EU agreement was made difficult by some of

\footnotetext{
${ }^{17} \mathrm{https}$ ://www.reuters.com/article/us-europe-asia-bank/u-s-urges-allies-to-think-twice-beforejoining-china-led-bank-iduskbn0md0b320150317.

${ }_{18} \mathrm{http}$ ://foreignpolicy.com/2015/03/23/chinas-transatlantic-wedge/?wp_login_redirect $=0$
} 
the EU member states' strong economic ties to China: 'China divides and rules, for example regarding EU policies following the arbitrary court' (Interview 24/10-2017). More precisely, 'Greece, Hungary and Cyprus are more friendly towards China' and did not want to sign the initial statement that was already developed by the EEAS (Interview 27/10-2017). Eventually, however, after 72 hours of intense negotiations, EU member states came to agreement and Mogherini issued a very general statement on behalf of the EU (Norman 2016). As underlined by several of the interviewees, this happened even if the US had 'put pressure on the EU (...) to produce a strong statement in favour of the ruling', in support of the US and its ally, the Philippines (Interview 25/10-2017).

\section{Summary and conclusion}

Without doubt, the security relationship between the EU and the US remains strong. As discussed in Howorth's article on NATO and the EU's common foreign and security policy (the CSDP), transatlantic relations 'will continue to exist as a meaningful entity in world politics - at least for the foreseeable future' (Howorth 2018). Most European states still rely on the US as their main security provider, and although perhaps for different reasons, legal considerations underline and unite their policies in both of our cases: In Ukraine the sovereignty principle, and in the South China sea the Law of the Seas. Not surprisingly, we also find that the EU is a soft and the US a hard power in the two regions: While the US has increased its military power both in Europe and in the Asia-Pacific in response to Russia and China's territorial claims, the EU so far foremost draws on its economic and diplomatic means in its dealing with these countries.

Nevertheless, in line with the second of our hypotheses, although this varies somewhat across the cases, our findings point towards a certain weakening of EU-US security relations in light of the crises' in Ukraine and the South China Sea as the EU develops a more coherent, autonomous and independent policy vis-à-vis the US. We do not find much support for a planned balance of power-hypothesis, with the EU joining the US as a junior partner. When it comes to Ukraine, the EU and US are indeed coordinated in their response to the Russian aggression, but mainly on the economic sanctions. There are no signs of the EU being part of a concerted balancing game, instead it has been criticized for ignoring geopolitics. The EU and the US do not seem to coordinate their policies towards China on the issue of the South China Sea as much as the US wants. To the contrary - as we have seen, our interviewees suggest that the US does not really want the EU to become a security actor in the region. In some cases, such as with the Asian Investment Bank and the EU's response to the UNCLOS arbitrary court ruling in 2016, the EU has even acted contrary to the US's wishes, despite US' calls for a 
different policy. The EU does not simply follow the US' lead, but displays an ambition of becoming a more autonomous actor, determined not only to take more responsibility for its neighborhood but also having a global aim. Although perhaps not a global super power in the traditional meaning of the term, geopolitical crises and conflicts serve to strengthen EU foreign and security cooperation.

The Trump presidency threatens to strengthen the weakening trend suggested in this article. Not only is the Trump-administration asking Europe to take more responsibility for its own security. Perhaps more importantly, and in support of what is argued elsewhere in this volume (Anderson 2018; Peterson 2018; Smith 2018), there is also evidence to suggest an increasing loss of trust between the EU and the US (Interviews 2017). Following the 2016 US Presidential election, several EU official interviewees suggested that 'the EU doesn't trust the US anymore' (Interview 2017). Similarly, 'the EU is dependent on both China and the US. It comes down to whether or not we need the US to defend us against Russia. If so, we would support the US with China. But the US has not really helped the EU with Ukraine' (Interview 24/10-2017). Most importantly, should the conflict in the South China Sea get hot, the US will have to more or less redraw from Europe, which will have to take a greater responsibility for its own security, in cooperation with or independently of the US (Interviews 2017). Although more studies are needed to support this, our findings suggest the latter: A stronger and more autonomous EU in a weaker EU-US relationship.

\section{References}

Anderson, J.G. (2018): 'Rancor and Resilience in the Atlantic Political Order: The Obama Years' in 'Crises and EU-US Relations', special issue, Journal of European Integration, July 2018

Auer, S. (2015). 'Carl Schmitt in the Kremlin: the Ukraine crisis and the return of geopolitics', International Affairs, 91, no. 5: 953-968.

Biscop, S. (2013) 'Peace without money, war without Americans: challenges for European strategy’, International Affairs, 89, no. 5: 1125-1142.

Bretherton, C., \& Vogler, D. (2006). The European Union as a global actor London: Routledge, 2nd ed.

Brooks. S. G and W.C. Wohlforth (2016). The Rise and Fall of the Great Powers in the TwentyFirst Century. China's Rise and the Fate of America's Global Position International Security, 40, no. 3: 7-53. 
Böller, F. and S. Werle (2016). 'Fencing the bear? Explaining US foreign policy towards Russian interventions', Contemporary Security Policy, 37, no. 3: 319-340.

Casier, T. (2016). 'The EU and Russia: a marriage of convenience', in Smith, M., Keukeleire, S. and Vanhoonacker, S. (eds.) The Diplomatic System of the European Union London: Routledge

Deitelhoff, N. (2009). 'The discursive process of legalisation: Charting Islands of persuasion in the ICC case', International Organization, 63, 33-65.

Duchâtel, M. (2016). 'The European Union's 'Principled Neutrality' - Can it Achieve Anything?', Sense and Sensibility. Addressing the south China Sea disputes, EU Institute for Security Studies Report no 28, May 2016: 53-56.

Duke, S. and C. Gebhard (2017). 'The Eu and NATO's dilemmas with Russia and the prospect for deconfliction', European Security, 26, no.3: 379-397.

Forbrig, J. (2015) (ed.). 'A Region Disunited - Central European Responses to the RussiaUkraine Crisis', Europe Policy Paper, 1/2015, Washington: The German Marshall Fund of the United States

Garamone, J. (2015). 'U.S. Outlines Asia-Pacific Maritime Security Strategy, DoD News, Defense Media Activity, US Department of Defence, https://www.defense.gov/News/Article/Article/614488/us-outlines-asia-pacific-maritimesecurity-strategy/

Gehring, T., K. Urbanski, and S. Oberthür (2017) 'The European Union as an Inadvertent Great Power: EU actorness and the Ukraine crisis', Journal of Common Market Studies, 55, no. 4: 727-743.

Haukkala, H. (2015) 'From Cooperative to Contested Europe? The Conflict in Ukraine as a Culmination of Long-Term Crisis in EU-Russia Relations', Journal of Contemporary European Studies, 23, no. 1: 25-40.

Haine, J.-Y. (2015). 'A new Gaullist moment? European bandwagoning and international polarity', International Affairs, 91, no. 5: 991-1008.

Howorth, J. (2017). 'Stability on the Borders: The Ukraine Crisis and the EU's Constrained Policy Towards the Eastern Neighbourhood', Journal of Common Market Studies, 55, no.1: 121-136.

Howorth, J. (2018). Strategic autonomy and EU-NATO Cooperation: threat or opportunity for transatlantic defence relations? special issue, Journal of European Integration, July 2018

Hyde-Price, A. (2006). 'Normative' power Europe: A realist critique', Journal of European Public Policy, 13, no.2: 217-234. 
Jupille, J. and J. A. Caparoso (1998) 'States, Agency, and Rules: The European Union in Global Environmental Politics', in Rhodes, C. (ed.) The European Union in the World Community London: Lynne Rienner Publishers: 213-230.

Jørgensen, K.E. Aarstad, Å.K, Driesken. E. Laatikainen. K and Tonra, B. (eds) (2015) The Sage Handbook of European Foreign Policy. Los Angeles, London, New Dehli, Singapore, Washington D.C.. Boston: SAGE

Kichner, J.E., T. Christiansen, and H. Dorussen (2016) (eds.), ' EU China Security Cooperation in Context', in Kichner, T. Christiansen, and H. Dorussen Security Relations between China and the European Union: From Convergence to Cooperation? Cambridge: Cambridge University Press,

Kraska, J. (2011). Arctic Security in an Age of Climate Change, Cambridge: Cambridge University Press

Larson, D. W. (2018) 'Outsourced Diplomacy: The Obama Administration and the Ukraine Crisis', in Young, A. and Birchfeld, V. (eds.) Triangular Diplomacy among the United States, the European Union and the Russian Federation. Responses to the Crisis in Ukraine Basingstoke: Palgrave Macmilan: 55-76.

Layne, C. (2012). 'This Time It's Real: The End of Unipolarity and the Pax Americana', International Studies Quarterly, 56, no. 1: 203-213

MacFarlane, N. and A. Menon (2014) 'The EU and Ukraine', Survival, 56, no. 3: 95-101.

Mearsheimer, J. J. (2014a). 'Why the Ukraine Crisis is the West's Fault: The liberal delusions that provoked Putin', Foreign Affairs, 39, no. 5: 77-89.

Mearsheimer, J. J. (2014b): Can China Rise Peacefully? The National Interest, 25/10-2014 at $\mathrm{http} / / /$ nationalinterest.org/commentary/can-china-rise-peacefully-10204

Mearsheimer, J.J. and S. Walt (2016). 'The Case for Offshore Balancing', Foreign Affairs July/August 2016: 70-83

Natorski, M. and K. Pomorska, K. (2017). 'Trust and Decision-making in Times of Crisis: The EU's Response to the Events in Ukraine', Journal of Common Market Studies, 55, no. 1: 5470.

Pejsova, E. (2016). 'Introduction: Light at the end of the tunnel?', in Sense and sensibility. Addressing the south China Sea disputes, EU Institute for Security Studies Report no 28, May 2016: 5-10.

Posen, B. (2003). 'Command of the commons: The Military Foundation of U.S. hegemony', International Security, 28, no. 1: 5-46.

Schleich, C. (2014). 'NATO and EU in conflict regulation: interlocking institutions and division of labour', Journal of Transatlantic Studies, 12, no. 2: 182-20.5 
Sjursen, H. and G. Rosén (2017). 'Arguing Sanctions. On the EU's response to the Crisis in Ukraine', Journal of Common Market Studies, 55, no. 1: 20-36.

Smith, M. E. (2015). 'The EU and the US', in Jørgensen, K.E. Aarstad, Å.K, Driesken. E. Laatikainen. K and Tonra, B. (eds) The Sage Handbook of European Foreign Policy. London: SAGE

Smith, M.E. (2018). 'Transatlantic Security Relations Since the European Security Strategy: What Role for the EU in Its Pursuit of Strategic Autonomy,' special issue, Journal of European Integration, July 2018

Smith, M. (2018): 'The EU, the US and the Crisis of Contemporary Multilateralism', in 'Crises and EU-US Relations', special issue, Journal of European Integration, July 2018

Tunsjø, $\emptyset$. ( 2015). 'China's Rise: Towards a Division of Labor in Transatlantic Relations', in Aggarwal, V. and Newland, S. (eds.) Responding to China's Rise: US and EU Strategies, Springer: 151-174.

Waltz, K. (2000). Structural realism after the Cold War. International Security, 25, no. 1: 5-41

Young, A. and Birchfield, V. (2017) 'Empirical Scene Setting: The Countours of the Crisis and Response', in Birchfield, V. and Young, A. (eds.) Triangular Diplomacy among the United States, the European Union, and the Russian Federation. Responses to the Crisis in Ukraine Basingstoke: Palgrave Macmillan: 21-54.

Youngs, R. (2010). The EU's role in world politics. A retreat from liberal internationalism. London: Routledge.

Yuan, J (2012). 'Emerging maritime rivalry in The South China Sea: Territorial disputes, sea-lane security, and the pursuit of power', International Security Research and Outreach Programme paper: http://www.international.gc.ca/isrop-prisi/assets/pdfs/Report-South_China_Sea.pdf 